\title{
Recenzja
}

\section{Bartłomiej Michalak, Partie protestu w Europie Zachodniej. Analiza relewancji politycznej, Wydawnictwo Adam Marszałek, Toruń 2008, ss. 312}

Sukcesy wyborcze partii protestu, takie jak efektowne wygrane Partii Wolności w Austrii czy Ligii Północnej we Włoszech, wywołały liczne dociekania i dyskusje, jaka jest natura tego typu formacji politycznych? Czy są one w stanie odtwarzać sukces wyborczy w kolejnych elekcjach? Na ile partie protestu są zdolne oddziaływać na kształt procesów zachodzących we współczesnych demokracjach? Tym niemniej, pomimo że przedmiotowa problematyka cieszy się zainteresowaniem badaczy, dostrzegamy deficyt opracowań i analiz kompleksowo obejmujących partie protestu, we wszystkich istotnych dla nich wymiarach funkcjonowania. Dominują ujęcia cząstkowe, a przy tym stosunkowo swobodnie operujące takimi pojęciami, jak „partie protestu” czy „partie populistyczne”. Obejmuje się nimi tak szeroki zakres desygnatów, że posługiwanie się nimi przestaje być zabiegiem klasyfikacyjnym. Użycie którejś z tych nazw w określonym kontekście może być formą wartościowania nazywanych przy ich pomocy partii politycznych. W ten sposób wykorzystywane pojęcia wytracają swój sens eksplanacyjny i zamieniają dyskurs naukowy w działalność stygmatyzującą, co w oczywisty sposób nie służy rzetelnym i obiektywnym badaniom na ten temat i zrozumieniu zjawiska partii protestu.

Próbą teoretycznego, a przy tym całościowego poddania analizie fenomenu partii protestu - zaznaczmy już w tym miejscu, że ze wszech miar udaną - jest analiza przeprowadzona przez Bartłomieja Michalaka w książce Partie protestu w Europie Zachodniej. Analiza relewancji politycznej. Wydało ją renomowane wydawnictwo naukowe - Wydawnictwo Adam Marszałek.

Jak podkreśla Bartłomiej Michalski, zabiegiem uniemożliwiającym zrozumienie specyfiki partii protestu jest ich wpisywanie w dychotomiczny układ lewica-prawica i umieszczanie na skrajnych pozycjach tego kontinuum. To bowiem, co wyróżnia te partie, to właśnie ich opozycyjność tak 
w stosunku do partii lewicowych, jak i partii prawicowych. „Pozycjonują się" one bowiem jako partie ani nie lewicowe, ani nie prawicowe, ale jako antysystemowe. Odczytywanie partii protestu przez pryzmat podziału lewica-prawica pomija również szereg strukturalnych i funkcjonalnych podobieństw zachodzących między nimi, umożliwiających postrzeganie tych ugrupowań jako reprezentujących ten sam typ partii. Nadmierne skupienie się na ich doktrynalnej i programowej charakterystyce prowadzi do sytuacji, w której najważniejszy aspekt ich funkcjonowania umyka z pola analizy. Jest nim właśnie ich polityczna antysystemowość, brak zgody na powszechnie aprobowany konsensus zarówno w sferze konfliktu politycznego, dotychczasowych procedur, instytucji, jak i uczestników zdarzeń politycznych. Istotą partii protestu jest przede wszystkim protest przeciwko określonym elementom i mechanizmom systemu politycznego. Dotyczyć on może różnych jego obszarów. Wielorakie mogą też być jego przyczyny i konkretne cele. Zawsze jednak sprzeciw jest skierowany wobec aktualnych stosunków społecznych i reprezentujących ten porządek elitom. Wyborcy partii protestu głosują nie tyle za określonym programem politycznym, ile przeciwko establishmentowi oraz konkretnym instytucjom politycznym. Jest to więc głos "protestu” przeciwko dominującym elitom politycznym, bez znaczenia czy o inklinacjach prolewicowych czy proprawicowych. Ulega on wzmocnieniu na skutek krytyki kierowanej pod adresem tych partii ze strony elit. Sukces partii protestu w znacznej mierze jest zasługą skutecznego przedstawiania siebie jako ruchu społecznego de facto niebędącego partią polityczną, swego rodzaju antypatii. Język negacji ma podkreślić antykonsensualny, radykalny i bezkompromisowy charakter podnoszonych kwestii. Ma je wyraźnie odróżniać od tradycyjnych partii politycznych.

Partie protestu, bez względu na konkretny charakter ideologiczny, moment ich powstania, formy działalności, organizację wewnętrzną i sukcesy wyborcze są wypadkową tych samych uwarunkowań. Również skutki, jakie wywierają w ramach poszczególnych systemów partyjnych, są zbliżone. Recenzowana książka jest udaną próbą odpowiedzi na pytania, jaki jest wpływ partii protestu na te systemy i czy skutki te mogą mieć istotne znaczenie dla ich funkcjonowania. Inaczej kwestię ujmując, clou postawionych pytań badawczych da się sprowadzić do pytania, na ile partie protestu są ugrupowaniami relewantnymi w ramach swoich systemów partyjnych? 
Główny cel badawczy w postaci charakterystyki roli i znaczenia partii protestu w zachodnioeuropejskich systemach partyjnych nakazał autorowi posłużyć się koncepcją relewancji politycznej. W tym celu bada takie problemy, jak: przyczyny, które zdecydowały o powstaniu partii protestu oraz zdeterminowały ich późniejsze sukcesy polityczne, prezentowany przez nie rodzaj apelu programowego i ideologicznego, charakter i formy działalności politycznej, uzyskiwane poparcie wyborcze, funkcjonowanie na forum parlamentu, udział w procesie przetargów gabinetowych, wpływ na kształtowanie polityki państwa oraz rolę partii protestu w procesie fragmentaryzacji i dekoncentracji europejskich systemów partyjnych. Postawione zagadnienia badawcze trzeba uznać za właściwie dobrane, a przy tym obejmujące całokształt problematyk składających się na zjawisko relewancji politycznej. Innymi słowy, ich analiza faktycznie pozwala ustalić rolę i znaczenie partii protestu w ramach systemów partyjnych.

Tak zarysowanym celom badawczym została podporządkowana struktura recenzowanej książki. Otwierają ją dwa rozdziały stwarzające teoretyczne podłoże dla analiz przeprowadzonych w dalszych partiach pracy (analiza pojęć właściwych dla partii protestu oraz analiza modelu relewancji politycznej). Z kolei w trzech kolejnych rozdziałach dokonano analizy partycypacji politycznej partii protestu w wymiarach kluczowych dla systemu partyjnego (wejście do systemu partyjnego, funkcjonowanie na arenie parlamentarnej, udział w przetargach rządowych, oddziaływanie na system partyjny). Zebrane w toku procesu badawczego obszerne dane empiryczne w postaci faktów politycznych dotyczących funkcjonowania partii protestu, formułowanych przez nie postulatów programowych oraz uzyskiwanych przez nie rezultatów wyborczych zostały dokładnie omówione, usystematyzowane i poddane interpretacji. Co istotne i co zarazem składa się na zdolność formułowania wniosków reprezentatywnych dla partii protestu jako takich, prowadzone rozważania mają charakter stricte porównawczy, co samo w sobie minimalizuje ryzyko przypadkowości uzyskiwanych wniosków. Każdorazowo cząstkowe rozważania przeprowadzone w poszczególnych rozdziałach znajdują podsumowanie w postaci cząstkowych wniosków bezpośrednio odnoszących się do stawianych w pracy subhipotez. Suma cząstkowych wniosków, artykułowanych w poszczególnych rozdziałach, komponuje obszerne wnioski całościowe, wyrażone w podsumowaniu recenzowanej monografii. 
Bartłomiej Michalak stawia hipotezę badawczą, w której następnie sukcesywnie dowodzi, że partie protestu dzięki rozmiarom osiągniętego poparcia społecznego stały się w pełni relewantne politycznie. Relewancja ta jest odnotowywana na wszystkich poziomach interakcji międzypartyjnych (poczynając od społeczno-publicznego, przez wybory, parlamenty, a na rządowym kończąc), choć w zależności od państwa, konkretnego ugrupowania oraz czasu jej wielkość podlega zróżnicowaniu. Ugruntowały swoją obecność na arenie parlamentarnej. Na stałe wpisały się w mechanizmy i reguły rywalizacji politycznej. Funkcjonowanie silnych partii protestu wywiera znaczny wpływ na strategie polityczne i zachowania pozostałych uczestników interakcji partyjnych. Oznacza to, że partii protestu nie można traktować jako zjawisk przejściowych. Co więcej, w świetle przeprowadzonych przez autora badań wyraźnie widać, że znaczenie partii protestu w systemie partyjnym, a poprzez niego również w systemie politycznym, nabiera na znaczeniu. To zaś może stanowić istotny bodziec w procesie zmiany systemów partyjnych. Sprzyja zasadniczym modyfikacjom w obrębie jego rdzenia, tj. przełamywaniu obowiązujących do tej pory wzorców rywalizacji politycznej reprodukowanych przez tradycyjnych aktorów politycznych i zastąpieniu ich nowym modelem interakcji. W ten sposób ugrupowania protestu zaczęły determinować kierunek ewolucji systemów partyjnych, co w konsekwencji rzutuje również na funkcjonowanie całego systemu politycznego.

W świetle przedstawionych przez autora analiz widać, że partie protestu odgrywają znaczącą i zwiększającą się rolę na forum rywalizacji wyborczej. Przechwytują niemały odsetek głosów społecznego niezadowolenia. Zarazem jednak relewancja poszczególnych partii protestu jest w znacznie większym stopniu zróżnicowana, niż ma to miejsce w odniesieniu do tradycyjnych sił politycznych. Zjawisko to autor Partii protestu... zasadnie wiąże z fluktuacyjnym charakterem głosów protestu. Są one realną i znaczącą siłą w ramach każdego systemu partyjnego, ale mają przy tym tendencję do przepływania między poszczególnymi ugrupowaniami. Z samej istoty poparcia niezadowolonych wynika, że jest ono agregowane emocjonalnie i stąd silnie uwarunkowane sytuacyjnie. Zwiększeniu ulega najczęściej w przypadku ogólnego pogorszenia koniunktury lub pojawienia się przekonań o kryzysie i niewydolności w funkcjonowaniu dotychczasowych mechanizmów decyzyjnych. Stabilizacji poparcia wyborczego nie sprzyjają również niska instytucjonalizacja tych ugrupowań oraz stopniowe zużywanie się głoszo- 
nych haseł programowych w sytuacji przechwytywania ich przez stronnictwa systemowe. Jak trafnie zaznacza Bartłomiej Michalak, największym zagrożeniem dla partii protestu nie są tradycyjne ugrupowania polityczne, ale inne partie antysystemowe zabiegające o ten sam płynny elektorat.

Niezaprzeczalnym walorem pracy jest postawienie w niej obok hipotezy wiodącej licznych subhipotez ułatwiających zrozumienie wielowymiarowości oddziaływań partii protestu na system partyjny. Jedną z takich subhipotez jest stwierdzenie, że tradycyjne partie polityczne starają się „neutralizować” partie protestu poprzez stosowanie strategii izolacji politycznej. Jednak im większa i stabilniejsza relewancja polityczna partii protestu na poziomie legitymizacji i inkorporacji, tym działania takie stają się coraz trudniejsze. To zaś ułatwia ugrupowaniom protestu uzyskanie akceptacji ze strony tradycyjnych uczestników interakcji międzypartyjnych. Motyw izolacji partii protestu jest także istotny na płaszczyźnie areny rządowej. Przełamanie monopolu ugrupowań tradycyjnych na udział w procesie przetargów koalicyjnych jest możliwe dopiero wtedy, kiedy siła polityczna partii protestu jest na tyle wysoka, iż dotychczas dominujący aktorzy polityczni są zmuszeni do zaakceptowania faktu obecności i znaczenia tych partii w parlamencie. Dopiero odpowiedni potencjał polityczny jest w stanie sprawić, że tradycyjne stronnictwa uznają je za ewentualnych partnerów politycznych.

Udział partii protestu w procesie interakcji międzypartyjnych na arenie rządowej jest zdarzeniem wywołującym nieodwracalne zmiany w sposobie funkcjonowania partii protestu i ich społecznej percepcji. Ugrupowania, których do tej pory głównym przeciwnikiem politycznym, odpowiedzialnym za całe zło stosunków społecznych, były dotychczasowy ład instytucjonalny i elity go reprodukujące, są w stanie stać się kluczowym elementem tego systemu, przejmując nad nim częściową kontrolę i odpowiedzialność za dalsze funkcjonowanie. W momencie, kiedy staje przed nimi możliwość wejścia w proces interakcji międzypartyjnych na arenie parlamentarnej i rządowej na warunkach zarezerwowanych dotychczas dla tradycyjnych uczestników tych relacji, powstaje presja tonowania radykalizmu, antysystemowości. Współrządzenie wymusza bowiem skupienie się na tych kwestiach programowych, które w danych warunkach politycznych są możliwe do osiągnięcia i odstawienie innych, dotychczas również intensywnie artykułowanych, ale co do których nie ma szans na realizację. 
Wydawałoby się paradoksalne, ale wzrost relewancji partii protestu może być źródłem wewnętrznej dekompozycji formacji politycznej i siłą napędową jej klęski. Partie nie mogą być jednocześnie efektywne w rządzeniu i antysystemowe w charakterze. Próba realizacji tych dwóch sprzecznych ze sobą funkcji musi prowadzić do kryzysu wewnątrz samej partii. Wejście przez partie protestu w skład koalicji rządowej, co należy odczytywać za najważniejszą postać politycznej partycypacji, z reguły wywołuje dysonans między dotychczasową a bieżącą definicją sytuacji politycznej tych partii. W rezultacie dochodzi do kryzysu tożsamości politycznej formacji. Jego następstwem jest brak skuteczności w zakresie artykulacji i realizacji dotychczas prezentowanego programu politycznego, a to $\mathrm{z}$ kolei często prowadzi do kryzysu wewnętrznego samej partii. Udział ugrupowań protestu w procesie przetargów gabinetowych zwykle przyczynia się do upodabniania się do koalicjanta $\mathrm{i}$ istotnego obniżenia poziomu radykalizmu politycznego przy jednoczesnym zaakceptowaniu najważniejszych instytucji, mechanizmów i uczestników krytykowanego do tej pory systemu politycznego. Partia stopniowo przekształca się z ugrupowania antysystemowej opozycji w ugrupowanie systemowe, z którym można prowadzić rutynowe przetargi polityczne i przez to staje się akceptowalna dla pozostałych uczestników rywalizacji partyjnej.

Będące konsekwencją interakcji międzypartyjnych upodabnianie się partii protestu do innych partii politycznych może być źródłem głębokich wstrząsów wewnątrz partii pomiędzy zwolennikami zachowania dotychczasowego, antysystemowego profilu partii i tymi, którzy chcieliby go modyfikować. Sytuacja taka prowadzi do kryzysu w partii protestu. Może się on zakończyć odejściem części członków, spadkiem poparcia społecznego, zmianą formuły politycznej czy rozpadem partii. Jak argumentuje Bartłomiej Michalak, w tym sensie okres pierwszej koalicji, w jakiej współuczestniczy partia protestu, w znacznym stopniu przesądza o jej przyszłości na rządowym poziomie rywalizacji politycznej.

Autor pracy Partie protestu w Europie Zachodniej. Analiza relewancji politycznej jednoznacznie akcentuje dwustronną zależność zachodzącą między kształtem systemów partyjnych a ugrupowaniami protestu. Podkreśla, że partie protestu są produktem określonej struktury międzypartyjnej, w której później funkcjonują. Jako ugrupowania stosunkowo młode nie uczestniczyły w tworzeniu systemów partyjnych. Pojawiły się już po ich „zamknięciu”. Jednakże przez sam fakt uczestnictwa w przetargach politycznych, i to 
nie tylko na arenie wyborczej, ale również parlamentarnej, a w niektórych państwach także rządowej, same współkształtują przebieg tych interakcji.

Recenzowana publikacja Bartłomieja Michalaka to godne polecenia studium, w którym na podstawie analizy rozległego materiału badawczego dochodzi się do pogłębionych wniosków teoretycznych. Połączenie badań praktycznych z rozważaniami teoretycznymi pozwoliło autorowi nie tylko sformułować wartościowe oceny zachodzących procesów w systemach partyjnych, ale jednocześnie nadać im walor uniwersalności.

Jacek Zaleśny (Uniwersytet Warszawski, Uczelnia Łazarskiego) 